Journal of Innate

Immunity
$\mathrm{J}$ Innate Immun 2010;2:303-304

DOI: 10.1159/000291025

Published online: February 27, 2010

\title{
Gary M. Bokoch
}

\author{
April 15, 1954 to January 10, 2010
}

We remember our colleague and friend Gary Michael Bokoch, who passed away on Sunday, January 10. His many students, colleagues, friends and family will sorely miss him.

Gary was born in Erie, Pennsylvania, to first-generation American parents. His grandparents had emigrated to the USA when they were hardly able to speak English and his grandfather worked as a coalminer. Gary was exceptionally bright and science was his chosen field. In 1976 Gary received his BSc in biology from Pennsylvania State University, and in 1981, a PhD in pharmacology from Vanderbilt University. His postdoctoral training was conducted under the guidance of Alfred G. Gilman at the University of Texas Health Science Center at Dallas.

The scientific life of Gary Bokoch was characterized by a unifying trait which started with his $\mathrm{PhD}$ thesis at Vanderbilt University and went on through his postdoctoral training to his 'mature' period at the Scripps Research Institute in La Jolla, California. The common denominator of his highly successful career was his interest in leukocyte function, starting with his early work on the role of arachidonic acid oxidation products and followed by his groundbreaking discoveries on the involvement of Rho GTPases in the regulation of oxygen radical production by phagocytes. His interest in GTP-binding proteins was nurtured during his postdoctoral training, working on the role of trimeric $G$ proteins in hormone signal transduction, and received a special impetus by his involvement in the discovery of the small GTPase Rac, in 1989. These were premonitions of one of his most notable future discoveries, the key role of Rac2 in the activation

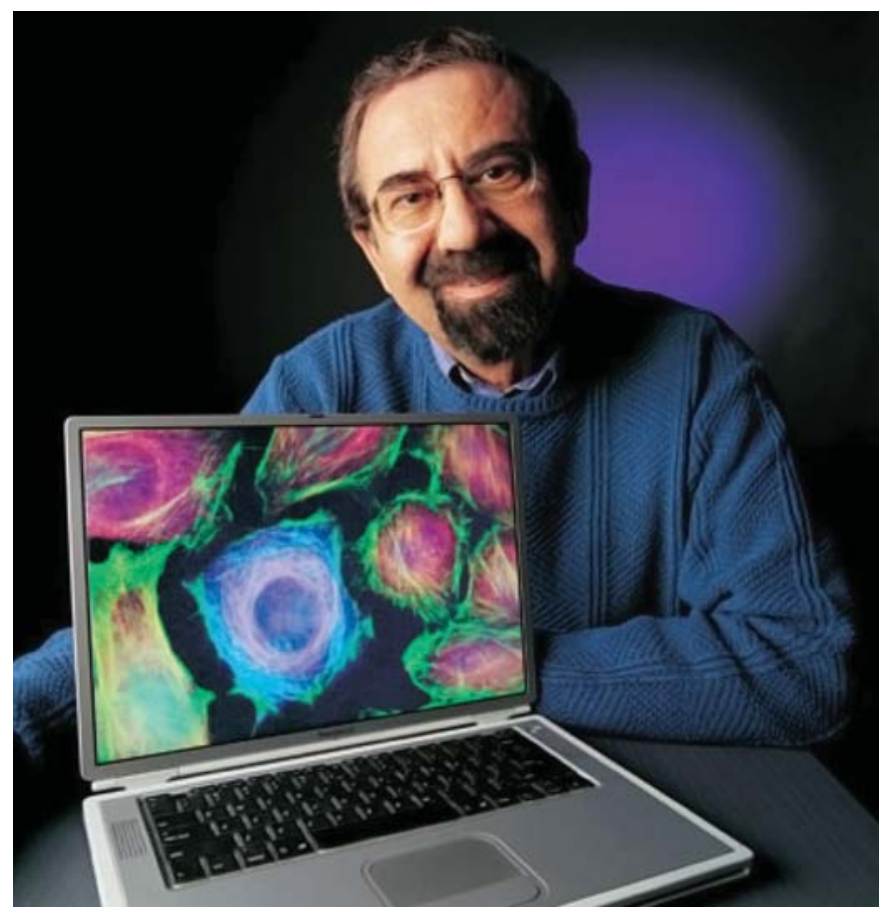

of the leukocyte NADPH oxidase. After his arrival at Scripps in 1985, Gary made important contributions to the study of chemoattractant receptors on leukocytes and to that of the small GTPase Rap1 (a subject that he never really abandoned).

One has a great difficulty deciding what Gary's most impressive contribution to science was. A fair guess is

\section{KARGER}

Fax +41 613061234 E-Mail karger@karger.ch www.karger.com
(C) 2010 S. Karger AG, Base

1662-811X/10/0023-0303\$26.00/0 
that his description, with Ulla Knaus, of the sine qua non involvement of Rac2 in NADPH oxidase activation in leukocytes will, forever, be associated with his name. This work was the catalyst for moving his research into numerous other areas, including seminal studies on the role of Rac-related regulators, such as Rho GDP dissociation inhibitor, guanine nucleotide exchange factors, GTPase activating protein, p21-activated kinases, phosphatidylinositol 3-kinase, and biologically active lipids. These were all splendid biochemical studies and Gary must have felt that cell biology could also profit from his exceptional investigative talents. Thus, from around 1995, his work became more cell-oriented and focused on the role of small GTPases in the regulation of cell motility and spreading, chemotaxis, membrane dynamics, and cytoskeletal organization in leukocytes and a variety of other cells, including cells infected with bacteria. Recently his lab described a nucleotide exchange factor GEFH1 that is uniquely regulated by microtubule binding and is crucial in coupling microtubule dynamics to Rho GTPase activation. This finding not only added to the mechanics underlying cell division but also uncovered a potentially powerful target for the next generation of cancer therapies that could interrupt the process of cell division at a key point. In the last decade of his life, Gary returned to the NADPH oxidase and carried out important work on the direct interaction of Rac with cytochrome $b 558$ and on the cross-talk between Rac and Cdc42, and he became involved in work on the nonphagocytic oxidases (Noxes), especially Nox1. Gary and his colleagues published more than 200 articles in top journals over the course of his career. His many excellent reviews made him a household name in all laboratories dealing with small GTPases and their broad impact on various aspects of biology.

His quiet, modest, and seemingly introvert manner fooled only those who did not know him closely. It took some time to get close to him but it was worth the effort. When the barriers went down, one discovered what a good and decent human being Gary really was, full of life and with a terrific sense of humor. Gary was also a loved and admired tutor who truly cared about his students and peers. Another of Gary's many qualities was the special relationship he had with his family. He was a loving husband to Janet, and an affectionate father to his two beloved daughters, Jennifer and Rebecca. We will remember Gary fondly in our hearts and feel lucky to have had the privilege to have known him.

Emanuel Hanski, Jerusalem Edgar Pick, Tel Aviv 